\title{
A kontinentális talapzat határaival kapcsolatos aktuális kihívások az Északi-sarkvidék példáján
}

\author{
Kontinentális talapzat - külső határok - tengerjog - Arktisz
}

A parti államokat megillető kontinentális talapzat, mint tengerjogi kategória, lassan százéves múltra tekint vissza, ennek ellenére jogi helyzetének meghatározása még napjainkban is kihívás. Elég csak arra gondolni, hogy milyen fejtörést okoz a szomszédos vagy szemben lévő államok között a pontos, mindenkinek megfelelő határok kijelölése - nemcsak az államoknak, hanem még a Nemzetközi Bíróságnak is.

A tanulmány azonban nem a szomszédok közötti határmegvonás kérdéseivel kíván foglalkozni, hanem egy 2001-ben kirajzolódó problémakört kíván elemezni, amely a kontinentális talapzatok külső, 200 tengeri mérföldön túli határaival kapcsolatban merült föl, és egyre inkább lázban tartja a világot. Az 1982-es, Montego Bayben kötött, jelenleg hatályos tengerjogi egyezmény (United Nations Convention on the Law of the Sea-UNCLOS) ugyanis úgy rendelkezik, hogy a parti állam 200 tengeri mérföldes távolságig egyoldalúan vonhatja meg kontinentális talapzatának külső határát. $A$ Kontinentális Talapzat Bizottság (Commission on the Limits of Continental Shelf CLCS) ajánlása nyomán, a földrajzi összefüggés címén, még ezen túlmenően is kiterjeszthető az állami szuverenitás. Ennek gyakorlata azonban olyan fordulatokat hozott, amelyekre sem az egyezménynek, sem a CLCS eljárási szabályzatának a kidolgozásakor nem készültek fel. Ezt kívánja a tanulmány megvilágítani az Északisarkvidék példáján keresztül, ezen a területen ugyanis megmutatkozik mindazon problémák halmaza, amelyek a külső határok megvonásával kapcsolatban felmerülnek, és amelyek a közeljövőben megoldásra várnak.

\section{A kontinentális talapzat fogalma és a parti állam szuverenitása}

A kontinentális talapzat földrajzi értelemben az a sekély tengerfenék, amely a szárazföldektöl képez átmenetet a kontinensek és szigetek körül a mélyebb tengerfenékhez; jogi szempontból pedig az állam szárazföldi területéhez kapcsolódó, állandóan vízzel borított tengerfenék, ahol a földrajzi összefüggés címén a parti állam speciális gazdasági jogokat élvez. ${ }^{1}$ Ahogy a Nemzetközi Bíróság is megállapította a

* Dr. Csatlós Erzsébet doktorjelölt, SZTE ÁJTK, Nemzetközi Jogi és Európa-jogi Tanszék, csatlos.e@juris.uszeged.hu.

JARES, Vladimir: The Continental Shelf Beyond 200 Nautical Miles: the Work of the Commission on the Limits of the Continental Shelf and the Arctic, Vanderbilt Journal of Transnational Law, 42 (2009) 1272; 
Tunézia v. Líbia ügyben, a parti államok jogosítványai a kontinentális talapzaton kizárólag azon alapulnak, hogy az a parti állam szárazföldi meghosszabbítása. ${ }^{2}$

A kontinentális talapzat állami uralom alá vonásának története szorosan összefügg az államok nyersanyagéhségével. Az erre vonatkozó első igény az 1942-es, Venezuela és az Egyesült Királyság által kötött, a Paria-öbölre vonatkozó szerződésben merült fel, amely felosztotta a Venezuela és Trinidad közötti olajmezőket. ${ }^{3}$ Ezt követően a Truman-deklaráció fektetett le részletes szabályokat a kontinentális talapzat jogi helyzetére vonatkozóan, amelyet a parti állam meghosszabbításának tekintett egészen addig, ameddig az állam afelett a szuverenitását biztosítani tudja. ${ }^{4}$ Ezt követően a tengerjog kodifikációja során külön egyezménybe foglalták a parti állam és a kontinentális talapzat viszonyát, jelenleg pedig az UNCLOS szabályozza azt, amely a parti állam jogait a Truman-deklarációhoz képest jelentősen csökkenti. ${ }^{5} \mathrm{Ez}$ az Egyesült Államok esetében fontos tény. Az USA nem terjesztett elő kontinentális talapzattal kapcsolatos igényeket, ugyanis a mai napig sem ratifikálta az UNCLOS-t, emiatt a benne foglalt jogokkal sem élhet. ${ }^{6} 2007$. október 31-én a szenátus külügyi bizottsága támogatását adta ahhoz, hogy a szenátus ratifikálja az UNCLOS-t, mivel ennek hiányában a potenciális kontinentális talapzat iránti igényeinek sem lehet jövője, ráadásul a Nemzetközi Tengerfenék Hatóságnak sem lehet a tagja. ${ }^{7}$ Az USA ugyanakkor jelentős kontinentális talapzati igényekkel rendelkezik az Arktiszon, amelyeket azonban tradicionálisan a Truman-deklarációra alapít. ${ }^{8}$ Kérdés, hogy ha elhatárolásra kerül a sor, ki lehet-e zárni az UNCLOS 76. cikkének szokásjogi alapon való érvényesülését a Truman-deklarációban lefektetett, és az 1958-as kontinentális talapzatról szóló egyezménybe foglalt szabály javára, ugyanis az USA ez utóbbinak a részese. ${ }^{9}$

Visszatérve az egyezmény tartalmára, az UNCLOS alapján a parti állam kontinentális talapzata (continental shelf) a parti tengerén túlnyúló tenger alatti területek ten-

McDormand, Ted: The Continental Shelf Beyond 200 Nm: Law and Politics in the Arctic Ocean, Journal of Transnational Law and Policy, 18 (2009) 2, 162-167.

2 Continental Shelf (Tunisia/Libyan Arab Jamahiriya), Judgment, ICJ Rep.1982, 48, 47.

3 Treaty Relating to the Submarine Areas of the Gulf of Paria, Great Britain-N. Ir.-Venez., February 26, 1942, 205 LNTS 121. 1. cikk; O'ConnelL, Daniel P.: The International Law of the Sea, Vol. 1., Oxford, Clarendon Press, 1970, 470; McDormand (2009): i. m., 163.

4 L. Proclamation Concerning United States Jurisdiction over Natural Resources in Coastal Areas and the High Seas. [Truman Declaration] Department of State Bulletin. 13. (1945) 485.

5 Dinh, Nguyen, Quoc - Daillier, Patrick - Pellet, Alain: Droit international public. Paris, Libraire générale de droit et de jurisprudence, 1980, 622-624.

6 Browne, Marjorie A.: The U.N. Law Of The Sea Convention and The United States: Developments Since October 2003, CRS Report for Congres, Oct. 31. (2007) 4. http://www.fas.org/sgp/crs/row/RS21890.pdf (2011.01.29.); RICHARDson, Elliot L.: Power, Mobility and the Law of the Sea, Foreign Affairs, 58 (1980) 4, 902-919; MCDORMAN, Ted L.: Global Ocean Governance and International Adjudicative Dispute Resolution, Ocean \& Coastal Management, 43. (2000) 259.

7 BRowne: i. m., 6-8.; ISTED, Kathryn: Sovereignty in the Arctic: an Analysis of Territorial Disputes \& Environmental Policy Considerations, Journal of Transnational Law \& Policy, Vol. 18. (2009) No. 2. 364.

8 ISTED: i. m., 365.

9 Az USA 1958. szeptember 15-én írta alá, és 1961. április 12-én ratifikálta. Status of Treaty. http://treaties. un.org/Pages/ViewDetails.aspx?src=UNTSONLINE\&tabid=2\&mtdsg_no=XXI-4\&chapter=21\&lang=en\#Part icipants (2011.09.10.). 
gerfenekét és altalaját foglalja magában, a szárazföldi területének egész természetes meghosszabbításán a kontinentális perem külső széléig, vagy a parti tenger szélességének mérésére szolgáló alapvonaltól számított 200 tengeri mérföld távolságig, ha a kontinentális perem külső széle nem terjed ki eddig. ${ }^{10} \mathrm{~A}$ kontinentális perem (continental margin) a parti állam szárazföldjének elsüllyedt meghosszabbítását foglalja magában, és a talapzat (shelf), a lejtő (slope) és a küszöb (rise) tengerfenekéből (seabed) és altalajából (subsoil) áll. Nem foglalja magában a mélytenger medrét (deep ocean floor) az óceáni hátságokkal (oceanic ridges), illetve az alattuk fekvő altalajt. ${ }^{11}$ [1. ábra]

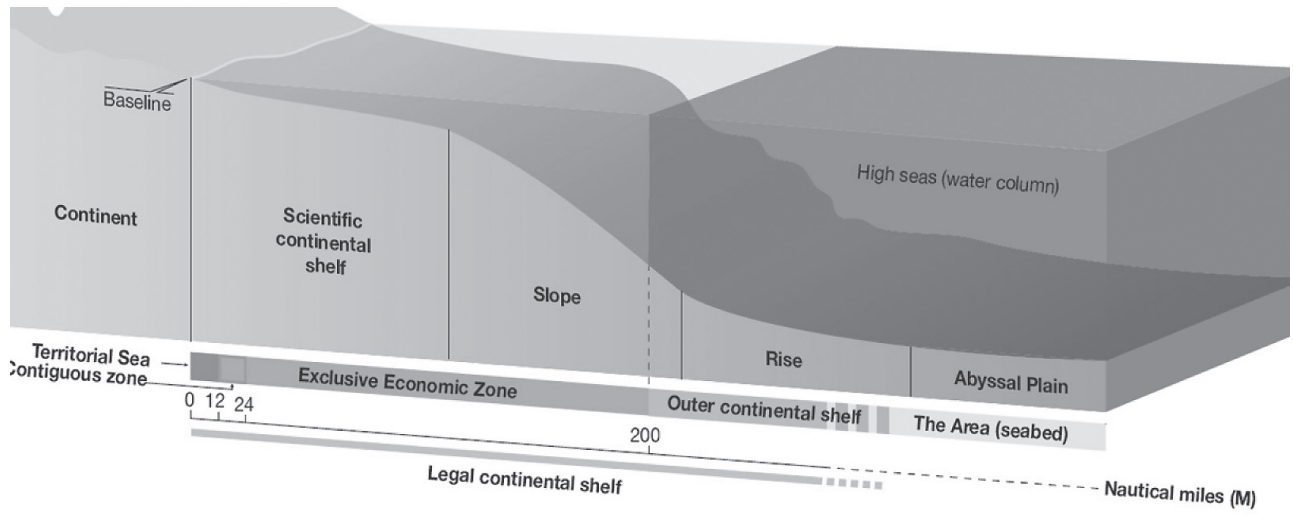

1. ábra - Tengeri zónák.

Peaceful Regulations of Ocean Space. Where does National Jurisdiction End? UNEP-GRID Arendal http://www.grida.no/publications/shelf-last-zone/page.aspx?id=4688 (2011.10.02.)

A parti állam a kontinentális talapzat felett a kutatás és a gazdasági kiaknázás tekintetében kizárólagos jogokat gyakorol, amelyek sem tényleges vagy jelképes elfoglalástól, sem kifejezett nyilatkozattól nem függenek. ${ }^{12}$

A természeti erőforrások a kontinentális talapzatra vonatkozó szabályozás szempontjából a tengerfenék és altalaj ásványi és más élettelen forrásaiból, valamint a fenéklakó fajokhoz tartozó élő organizmusokból állnak; azon organizmusokból, amelyek a begyüjtési szakaszban vagy mozdulatlanok a tengerfenéken, illetve az alatt vagy csak a tengerfenékkel, vagy az altalajjal szilárd fizikai kapcsolatban képesek elmozdulásra. ${ }^{13}$

Emellett viszont meghatározott feltételekkel ugyan, de minden államnak joga van tenger alatti kábelek és csővezetékek elhelyezésére a kontinentális talapzaton.

10 United Nations Convention on the Law of the Sea Montego Bay, 10 December 1982. 1833 U.N.T.S. 3. [UNCLOS] 76. cikk (1).; Az UNCLOS definíciójának elemeiről részletesen lásd, PHARAND, Donat: The Continental Shelf Redefinition, with Special References to the Arctic, McGill Law Journal, 18 (1972) 536-546.

11 UNCLOS 76. cikk (3).

12 UNCLOS 80. és 77. cikk; RIDDELL-DIXON, Elizabeth: Canada and Arctic Politics: the Continental Shelf Extension, Ocean Development \& International Law, 39 (2008), 348.

13 UNCLOS 77. cikk (4). 
A parti állam ezt nem akadályozhatja, de ésszerủ intézkedéseket tehet a saját jogai gyakorlása és a szennyezés megelőzése érdekében. ${ }^{14}$

A kontinentális talapzat kincseiből ugyanakkor nem csak annak parti állama részesül, az ugyanis az alapvonaltól 200 tengeri mérföldnél messzebbre található területek élettelen kincseinek kiaknázása után, a kitermelés megkezdését követő 5 éven túl már befizetésekkel és természetbeni járulékokkal tartozik a Nemzetközi Tengerfenék Hatóság (International Seabed Authority) felé. ${ }^{15} \mathrm{~A} 6$. évben a befizetés vagy a járulék mértéke az adott körzetben kitermelt termék mennyiségének vagy értékének $1 \%$-a. E mérték a 12. évvel bezárólag évente 1\%-kal növekszik, majd azt követően $7 \%$ marad. ${ }^{16}$

A befizetések és járulékok teljesítése a Nemzetközi Tengerfenék Hatóságon keresztül történik, amely azokat - méltányos elosztási feltételrendszer alapján - az UNCLOS részes államai között osztja szét, figyelembe véve a fejlődő államok szükségleteit és érdekeit, különös tekintettel a legkevésbé fejlett, valamint a tengerparttal nem rendelkező államokra. ${ }^{17}$

\section{A kontinentális talapzat kiterjedésével kapcsolatos szabályok és nehézségek}

\subsection{A kontinentális talapzat egyoldalú megvonása az érintett állam által}

A parti állam állapíthatja meg egyoldalú aktussal a kontinentális perem külső szélét minden olyan esetben, amikor a perem túlnyúlik az alapvonaltól számított 200 tengeri mérföldön, vagy

- a legtávolabbi rögzített pontokon át meghúzott vonal által, ha a pontok mindegyikénél az üledékes kőzetek vastagsága legalább 1\%-a az ilyen pontoktól a kontinentális lejtö lábáig mért legrövidebb távolságnak (Gardiner-formula/ír formula/sediment thickness formula) [2. ábra, Formula 1]; vagy

- a legtávolabbi rögzített pontokon át meghúzott vonal által, ha a pontok távolsága a kontinentális lejtő lábától nem több mint 60 tengeri mérföld (Hedberg-formula/ bathymetric formula/distance formula). ${ }^{18}$ [3. ábra, Formula 2]

14 UNCLOS 79. cikk.

15 UNCLOS 82. cikk (1).

16 UNCLOS 82. cikk (2)-(3).

17 UNCLOS 82. cikk (4).

18 UNCLOS 76. cikk (4) a); Kunor, Bjorn: A New Arctic Conquest: the Arctic Outre Continental Margin, Nordic Journal of International Law, 76 (2007) 469; MACNAB, Ron: The Case for Transparency in the Delimitation of the Outer Continental Shelf in Accordance with UNCLOS Article 76, Ocean Development \& International Law, 35 (2004) 6-7; ORTOLLAND, Didier - PIRAT, Jean-Pierre: Atlas géopolitique des espaces maritimes: frontières, énergie, pêche et environnement, Paris, Editions Ophrys, 2008, 200. 
A kontinentális talapzat határaival kapcsolatos, aktuális kihívások az Északi-sarkvidék példáján

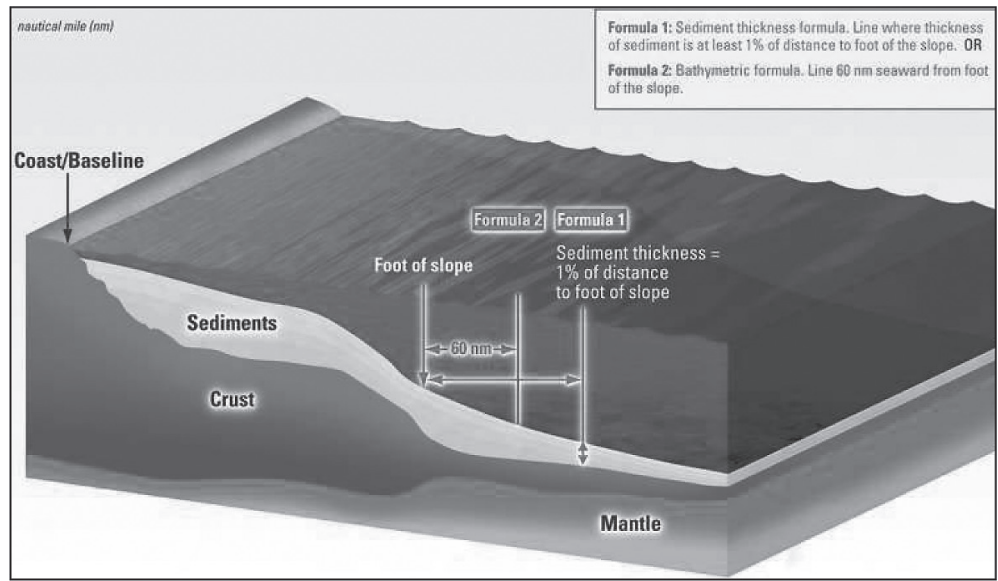

2. ábra - A kontinentális perem megállapítására alkalmazható formulák.

Forrás: Determining of the limits of the extended continental shelf.

http://continentalshelf.gov/missions/10arctic/background/shelf.html (2011.02.06.)

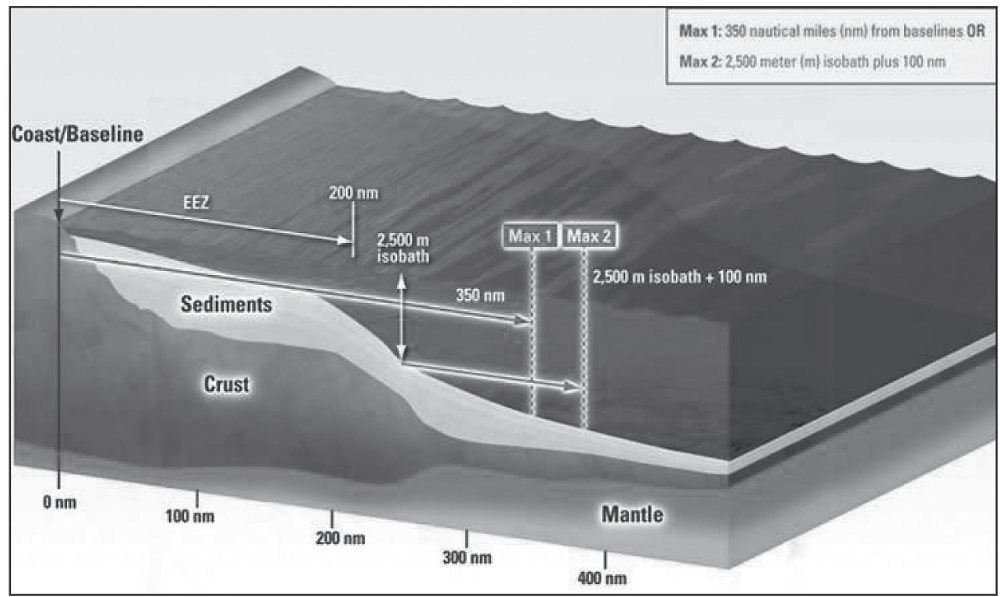

3. ábra - A kontinentális talapzat külső határa.

Forrás: Determining the limit of the extended continental shelf.

http://continentalshelf.gov/missions/10arctic/background/shelf.html (2011.02.06.)

Ellenkező bizonyítékok hiányában a kontinentális lejtő lábát a lejtő alján a lejtés maximális változásának pontjaként határozzák meg. ${ }^{19}$

A kontinentális talapzat külső határa azonban nem nyúlhat túl az attól az alapvonaltól számított 350 tengeri mérföldön $(648 \mathrm{~km})$, ahonnan a parti tenger szélességét mérik vagy a 2500 méteres izobáttól, a 2500 méteres mélységeket összekötő vonaltól mért 100 tengeri mérföldön $(185 \mathrm{~km}) \cdot{ }^{20}$ Ugyanígy, a 76 . cikk (5) bekezdésében

19 UNCLOS 76. cikk (4) b); KUNOY (2007): i. m., 470.

20 UNCloS, 76. cikk (6); Macnab: i. m., 7.; Ortolland-PiRat: i. m., 200.; Kunoy (2007): i. m., 470. 
megállapítottak ellenére, a tenger alatti hátságokon a kontinentális talapzat külső határa nem nyúlhat az alapvonaltól számított 350 tengeri mérföldön túl. Ez azonban nem vonatkozik azon tenger alatti kiemelkedésekre, melyek a kontinentális perem természetes alkotóelemei, úgymint a fennsíkjai (plateau), magaslatai (rise), fedőkőzete (cap), sziklapadjai (banks) és hegynyúlványai (spurs). ${ }^{21}$

A parti állam rajzolja meg kontinentális talapzatának külső határait, rögzített pontokat összekötő, szélességi és hosszúsági koordinátákkal meghatározott, legfeljebb 60 tengeri mérföld hosszúságú egyenes vonalakkal azokban az esetekben, amikor ez a talapzat túlnyúlik az attól az alapvonaltól számított 200 tengeri mérföldön, ahonnan a parti tenger szélességét mérik. ${ }^{22}$

\subsection{A kontinentális talapzat határának megvonása a CLCS közremüködésével}

A kontinentális talapzat határa az alapvonaltól számított 200 tengeri mérföldön belül tehát a parti állam egyoldalú aktusával megvonható. ${ }^{23}$ Amennyiben azonban a parti állam 200 tengeri mérföldön túl is igényt tart a kontinentális talapzat feletti kizárólagos állami jogosítványokra, akkor a 200 tengeri mérföldön túli rész tekintetében a határokra vonatkozó információt a parti állam a méltányos földrajzi részvétel alapján felállított Kontinentális Talapzat Bizottságnak köteles benyújtani. ${ }^{24} \mathrm{~A}$ CLCS szerepe kulcsfontosságú, ugyanis kizárólag annak eljárása nyomán lehet élni az UNCLOS 76. cikke által kínált lehetőséggel, és 200 tengeri mérföldön túli kontinentális talapzatrészekre is kiterjeszteni a külső határokat. Ez az egyik sarkalatos újitása az UNCLOS-nak, mivel a rendelkezéseknek megfelelően csak az egyezményben részes állam élhet az abban foglalt joggal. A 200 tengeri mérföldön túli kontinentális talapzatra vonatkozó állami jogosítványok létjogosultsága ugyanis soha nem volt szokásjogi szabály, és még nem is vált azzá, így a 76. cikk lehetőségeivel csak az az állam jogosult élni, amely az egyezményben foglalt kötelezettségeket is felvállalta azáltal, hogy annak részesévé vált. ${ }^{25}$

Az ezzel ellentétes nézetek arra alapoznak, hogy a kontinentális talapzat a szárazföldi terület természetes meghosszabbítása, és ez független mindenféle távolsági limittől. Ha a CLCS előtt nem csak az UNCLOS részes államai indíthatnának eljárást, ${ }^{26}$ az sem változtatna viszont azon, hogy a nem részes államok nem az UNCLOS 76. cikke alapján terjesztik ki az uralmukat, így az általuk kijelölt - akár a CLCS által

UNCLOS 76. cikk (5).

22 Uo. 76. cikk (7).

23 JARES: i. m., 1265.

24 UNCLOS II. jegyzőkönyv; KunOY (2007): i. m., 466.

25 Wolfrum, Rüdiger: The Outer Continental Shelf: Some Considerations Concerning Application and the Potential Role of the International Tribunal for the Law of the Sea, Presentation at 73rd Biennial Conference of the International Law Association, Rio de Janeiro, Brazil, 21 August 2008, 5-6. http://www.itlos.org/ fileadmin/itlos/documents/statements_of_president/wolfrum/ila_rio_210808_eng.pdf (2011.10.03.).

26 Az eljárási szabályok általános jelleggel a parti államot (coastal State) jelölik meg a beadvány előterjesztésére jogosultnak, és nem az UNCLOS-ban részes állam terminológiáját használják, viszont kifejezetten az UNCLOS adott állam vonatkozásában kezdődő időbeli hatályát jelöli meg a beadvány beterjesztésére rendelkezésre álló időtartam kezdeteként, és ilyen dátummal nyilvánvalóan csak az egyezményben részes 
adott javaslatnak megfelelő - külső határok a 76. cikk 8. pontja alapján nem lesznek véglegesnek és kötelezőnek tekintendőek (final and binding). Ennek fényében kérdés, hogy vajon az ipar mennyiben fogja támogatni az olyan terület hasznosítását, amelyen nem nemzetközileg elismert eljárás alapján jelölték ki a határokat, amelyek így nem tekinthetőek sem véglegesnek, sem mások által tiszteletben tartandónak. Az Arktiszon ez a probléma legfőképpen az USA miatt merül föl, hiszen az egyelöre nem részese az UNCLOS-nak, a CLCS felállításakor ülésező testület pedig annak ellenére, hogy tárgyalt a szóban forgó kérdésről (vagyis az egyezményben nem részes államok és a 200 tengeri mérföldön túli külső határok viszonyáról), végül nem alakított ki erre vonatkozóan álláspontot. ${ }^{27}$

A CLCS 21 olyan tagból áll, akik a geológia, geofizika vagy hidrográfia szakértői, akiket az UNCLOS részes államai választanak állampolgáraik közül a földrajzilag arányos képviselet elvének betartásával. ${ }^{28}$ Az UNCLOS 1994-ben lépett hatályba, a CLCS munkája 2001-ben kezdődött meg, vagyis abban az évben, amikor az Arktisz kontinentális talapzat iránti verseny is megindult. Oroszország volt a világon - és az Arktiszon - az első állam, amely élt a 76. cikk adta lehetőséggel, és beadványban kérte a kontinentális talapzatának 200 tengeri mérföldön túli kiterjesztését. ${ }^{29}$

A CLCS ajánlásokat tesz a parti államoknak a kontinentális talapzataik külső határainak megállapításával kapcsolatos kérdésekben, amelyek alapján a parti állam által megállapított talapzathatárok véglegesek és kötelezőek lesznek. ${ }^{30}$ Ez a hovatartozási vizsgálaton alapul (test of appurtenance), amely annak bizonyítására irányul, hogy az adott terület valóban annak az államnak a kontinentális talapzata, amelyik arra vonatkozóan igényekkel lép fel. ${ }^{31}$ Amennyiben egy parti állam, a 76. cikkel összhangban, meg akarja állapítani kontinentális talapzatának 200 tengeri mérföldön túlnyúló külső határait, akkor haladéktalanul, de legkésőbb az UNCLOS-nak az adott állam tekintetében történő hatálybalépését követő 10 éven belül be kell nyújtania a CLCS-hez az igényt, és az azt alátámasztó tudományos adatokat. ${ }^{32} \mathrm{Az}$ állam ezzel egyidejüleg köteles megadni a bizottság azon tagjainak a nevét, akik részére müszaki-tudományos konzultációt nyújtottak. ${ }^{33}$

állam rendelkezik. Rules of Procedure of the Commission on the Limits of the Continental Shelf, Twenty-first session, 17 March-18 April 2008, UN Doc. CLCS/40/Rev.1. [Rules of Procedure] 45.

27 Wolfrum: i. m., 7.

28 UNCLOS II. sz. melléklet 2. cikk (1); Kunor (2007): i. m., 467.

29 A beadvány pontos tartalma az orosz állam kérésére nem publikus, így csak az igényelt területet jelző térképükből és a beadványt kommentáló kanadai, dán, norvég és amerikai hivatalos reakciókból lehet következtetni az igények jogalapjára és terjedelmére. JARASHOW, Mark: UNCLOS and the Arctic: The Path of Least Resistance, Fordham International Law Journal, 30 (2007) 1587, 1591; CoHEN, Ariel: Russia's Race for the Arctic. The Heritage Foundation, (2007) 1582. 1-2.

30 UNCLOS 76. cikk (8).

31 Riddell-Dixon (2008): i. m., 345.; Macnab: i. m., 3.

32 Issues with Respect to article 4 of Annex II. to the Convention (ten-year time limit for submission) http://www. un.org/Depts/los/clcs_new/issues_ten_years.htm (2011.09.05.).

33 Rules of Procedure, 45. Az I. és II. számú mellékletet a 4. ülésen,1998. augusztus 31. és szeptember 4. között fogadták el, a III. számú mellékletet a 13. ülésszak alatt, 2004. április 26-30. között fogadták el. L. Commission on the Limits of the Continental Shelf (CLCS), Selected Documents of the Commission. http:// www.un.org/Depts/los/clcs_new/commission_documents.htm\#Rules\%20of\%20Procedure (2011.02.06.). 
Az egyik probléma, ami a kontinentális talapzat külső határainak megállapításával kapcsolatban felmerül, éppen a 10 éves szabály, amelynek tekintetében az egyezményben részes államok között vita alakult ki. Ennek a szerződések jogáról szóló bécsi egyezmény (Vienna Convention on the Law of Treaties - VCLT) alapján számottevő jelentősége van, ugyanis a szerződés rendelkezései szerint bármely, a szerződésben részes felek közötti, utólagos megegyezés a szerződés értelmezésénél figyelembe veendő. ${ }^{34}$ Végső soron az az informális megegyezés született, hogy elegendő, ha a 10 éves időszakban csak előzetesen jelzik, hogy szándékukban áll igénnyel fellépni a CLCS elött a kontinentális talapzatuk 200 tengeri mérföldön túli határának delimitálása iránt. ${ }^{35} \mathrm{Ez}$ az állásfoglalás az UNCLOS egyszerüsített módosítási eljárásra vonatkozó szabályok szellemében, ${ }^{36}$ valamint a felek későbbi módosításnak minősülő gyakorlatára vonatkozó szokásjog fényében ${ }^{37}$ követendőnek minősül. ${ }^{38}$ Tekintettel arra, hogy a 10 éves időszak még sok állam esetében nem járt le, és 2011. szeptember 7-ig összesen 57 állam élt az igénylés lehetőségével, és eddig 54 esetében került konkrétan napirendre a kérdés, amiböl 18 esetben állították fel az igényekkel konkrétan foglalkozó albizottságot, és mindössze 14 esetben született meg az ajánlás, ezért kiforrott gyakorlatról még nem beszélhetünk. ${ }^{39}$

Fontosak az informális szabályok, ugyanis az idő múlik, és az Arktisz jelentős tengerparttal - vagyis feltehetően nagy igénnyel is - rendelkező államai közül Kanada (amely 2003. november 7-én ratifikálta az UNCLOS-t, de a mai napig sem nyújtott be igényt a CLCS-hez ${ }^{40}$ ) azon dolgozik, hogy bebizonyítsa: az Alpha-hátság - egy 2000 km hosszú, víz alatti hegységhálózat - a kanadai kontinentális talapzat része (jelenleg a kutatási eredmények még nem elegendőek egy megalapozott beadvány elkészítéséhez. $)^{41}$

34 Vienna Convention on the Law of Treaties, 23 May 1969, 1155 UNTS 331 [VCLT]. 31. cikk (3) bekezdés a) pont.; Case Concerning the Territorial Dispute (Libyan Arab Jamahiriya/Chad), Judgement [1994] ICJ Rep., 41.

35 Decision regarding the date of commencement of the ten-year period for making submissions to the Commission on the Limits of the Continental Shelf set out in article 4 of Annex II to the United Nations Convention on the Law of the Sea (29 May 2001). UN Doc. SPLOS/72. a) pont; Decision regarding the workload of the Commission on the Limits of the Continental Shelf and the ability of States, particularly developing States, to fulfil the requirements of article 4 of Annex II to the Convention, as well as the decision contained in SPLOS/72, paragraph (a). (20 June 2008.) UN Doc. SPLOS/183.; Kunor, Bjorn: The 10 Year Time Frame to Disputed Areas, Ocean Development \& International Law, 40 (2009) 132.

36 UNCLOS 313. cikk.

37 KunOY (2009): i. m., 140.

38 Kunor (2009): i. m., 132.

39 Submissions, through the Secretary-General of the United Nations, to the Commission on the Limits of the Continental Shelf, pursuant to Article 76 paragraph 8 of the United Nations Convention on the Law of the Sea of 10 December 1982. http://www.un.org/Depts/los/clcs_new/commission_submissions.htm (2011.09.08.).

40 Boswell, Randy: Canadian Expedition Seeks to Prove Claim on Underwater Ridge, National Post, Toronto, February 15 (2008) http://www.nationalpost.com/news/canada/story.html?id=311913. (2011.01.30.); Defining Canada's Continental Shelf. http://www.international.gc.ca/continental/limits-continental-limites. aspx?lang=eng\&menu_id=20\&menu=R (2011.02.11.) IsTED: i. m., 357.

41 Canada's Extended Continental Shelf, http://www.international.gc.ca/continental/index.aspx?lang=eng (2011.01.28.); Berthiaume, Lee: Icebreaker Replacement Deadline Looms. Embassy Ottawa, Feb. 27. (2008) 1.; 10. http://embassymag.ca/pdf/view/2008-02-27 (2011.01.28.). 
Visszatérve, a parti állam az ENSZ főtitkáránál helyezi letétbe a tengerészeti térképeket, és a kontinentális talapzat külső határaira vonatkozó adatokat, aki azokat közzéteszi, ${ }^{42}$ kiértesítve az ENSZ - és nem csak az UNCLOS - összes tagállamát, majd az értesítéstől számított 3 hónapon túl napirendre tűzi a beadvány tárgyalását, és legalább 60 nappal az ülés megnyílta előtt értesíti a benyújtó tagállamot. ${ }^{43}$

Amennyiben a CLCS másképp nem dönt, akkor 7 tagból álló albizottságok útján müködik, amelyek tagjait kiegyensúlyozott módon jelölik, figyelembe véve a parti állam beadványának speciális elemeit. A beadványt benyújtó állam állampolgárságával rendelkező bizottsági tagok, és bármely bizottsági tag, aki a parti állam részére múszaki-tudományos segítséget nyújtott, a határok megállapítása tekintetében, nem lehet tagja annak az albizottságnak, amely az adott beadványt elbírálja. A beadványt benyújtó parti állam képviselői szavazati jog nélkül az adott eljárásban részt vehetnek. ${ }^{44}$

Az albizottságok ajánlásaikat a CLCS-hez nyújtják be, amely azt a jelen levő és szavazó tagjainak $2 / 3$-os többségével fogadja el, amit aztán írásban juttatnak el a beadványt előterjesztőhöz, valamint a főtitkárhoz. ${ }^{45}$

A parti államok az ajánlás birtokában a megfelelő nemzeti eljárásokkal összhangban állapítják meg a kontinentális talapzat külső határait, ${ }^{46}$ figyelembe véve azt, hogy a CLCS aktusai nem befolyásolják a szemben elhelyezkedő vagy érintkező partokkal rendelkező parti államok elhatárolását érintő ügyeket. ${ }^{47} \mathrm{Az}$ ajánlást írásban juttatják el a beadványt előterjesztő tagállam, valamint a főtitkár számára. ${ }^{48}$ Amennyiben a parti állam nem ért egyet a CLCS ajánlásaival, ésszerü határidőn belül köteles új vagy átdolgozott beadványt előterjeszteni. ${ }^{49}$ A CLCS ajánlása egyéb esetekben kötelező és végleges, de esetenként további lépésekre kötelezi az államot, hogy később olyan beadványt tudjon benyújtani, amely alapján a CLCS megfelelő módon meg tudja ítélni, hogy vajon az igényelt terület valóban az igénylő állam szárazföldi területének meghosszabbítása. ${ }^{50} \mathrm{Az}$ Arktiszon Oroszország esetében fordult elő, hogy a CLCS úgy döntött, hogy több információra van szükség az orosz kontinentális talapzat külső határára vonatkozó állásfoglalás kialakításához. ${ }^{51}$

42 UNCLOS 76. cikk (9); 84. cikk.

43 Rules of Procedure 50-52.

44 UNCLOS II. sz. melléklet 5. cikk.

45 Uo. 6. cikk.

46 Uo. 7. cikk.

47 Uo. 9. cikk.; Rules of Procedure 46.

48 Rules of Procedure 53. 3.

49 UNCLOS II. sz. melléklet 8. cikk.; Rules of Procedure 53. 4.

50 Rules of Procedure 53. 5.

51 Paradox módon az UNCLOS-ban nem részes USA hozzászólásaiból tudunk a legtöbbet az orosz igény tartalmáról, amelynek kapcsán kritikaként merült fel a pontos geográfiai adatok hiánya, valamint a logikai kapcsolat kimutatása a térképen igényként megjelölt területek és az UNCLOS 76. cikke között. - The Secretary-General, Report of the Secretary-General on Oceans and the Law of the Sea, delivered to the Security Council and the General Assembly, 7 March, 2002, U.N. Doc. A/57/57. [U.N. Doc. A/57/57.] 38-41. pont; Ostroff, Ethan, G.: International Law in the News: Russia's Claim to the Arctic, ILSA Quarterly, 16 (2007) 131. 
A CLCS munkájának egyik legföbb támasza a Tudományos és Technikai Útmutató [Útmutató], amelyet 1999. május 13-án fogadtak el, ${ }^{52}$ de számos alkalommal módosítottak, illetve kiegészítettek. ${ }^{53}$ A CLCS ugyan nem kapott felhatalmazást az eljárási szabályainak a kidolgozására, de mivel a feladata végzéséhez szüksége volt rá, ezért megalkothatta azokat. ${ }^{54}$

A legfőbb korlát a CLCS-eljárásban egyébként az államok kooperációjának hiánya, ugyanis a területi vita tárgyát képező területek vonatkozásában nem adhat ajánlást, hacsak nem kapja meg az érintett államok mindegyikének hozzájárulását. ${ }^{55}$ Ennek oka, hogy a külső határ megvonásában hozott döntéssel nem akarja, és nem is teheti, hogy prejudikálja az államok közötti határmegvonási kérdést. ${ }^{56}$ Vita fogalma alatt a Mavrommatis-ügyben lefektetett, klasszikus definíciót kell érteni, amely minden jogi és ténybeli érdekellentétet felölel. ${ }^{57}$ Az ellenkezés bármilyen formája az adott államok közötti vitának minősül, amely olyan területet érint, amelyre több állam is igényt tart. ${ }^{58}$ Ilyen, egymást átfedő igények esetében az érintett területre vonatkozóan az államok megegyezése, vagy olyan beadvány benyújtása lehet a megoldás, amely eleve csak olyan térségre nézve kéri a CLCS eljárását, amelyen más állam igénye potenciálisan sem áll fenn. E tekintetben példaértékű a norvég-dán-izlandi kooperáció.

Norvégia ugyanis további $250000 \mathrm{~km}^{2}$-t szeretett volna a már meglévő kontinentális talapzatához csatolni, amely a Barents-tenger alatti, ún. Loop-mélyedést, a Norvég-tenger alatti Banana-mélyedést, valamint a Jeges-tenger alatt húzódó NyugatNansen-medencét foglalja magában. ${ }^{59}$ Nemcsak a saját igényeit vázolta, hanem részletesen kitért arra is, hogy melyek azok a területek, amelyeken más államok igényével is számolni lehet: a Barents-tengeren a Loop-mélyedés, valamint a Jegestengeren a Nyugat-Nansen-medence is orosz-norvég területi vita tárgya az igényátfedések miatt. ${ }^{60}$ Eddig egyedül a Barents-tengerre vonatkozó 40 éves határvitát si-

52 CLCS/11 - Scientific and Technical Guidelines of the Commission on the Limits of the Continental Shelf, 13 May 1999. [CLCS Guidelines]

53 CLCS Guidelines. http://www.un.org/Depts/los/clcs_new/commission_guidelines.htm (2011.02.11.).

54 A nemzetközi jog általános szabályai alapján, egy egyezmény alapján létrehozott szerv implicit módon rendelkezik a saját működési rendje megállapításának jogával, akkor is, ha erről a szerződés nem rendelkezik. Reparations for Injuries Suffered in the Service of the United Nations, Advisory Opinion, [1949] ICJ Rep. 182.; Kunoy (2009): i. m., 183.

55 Rules of Procedure, Annex I. 5. cikk. ("Rule 5"); MacnaB: i. m., 11-12.; Symmons, Clive R.: The Irish Partial Submission to the Commission on the Limits of the Continental Shelf in 2005: a Precedent for Future Such Submissions in the Light of the "Disputed Areas" Procedures of the Commission? Ocean Development \& International Law, 37 (2006) 304-305.

56 UNCLOS, 76. cikk (10); Kunoy (2009): 134-135.

57 Mavrommatis Palestine Concessions (Greece v. United Kingdom) Judgement on Jurisdiction [1924] PCIJ Rep. Series A, 11.; Case Concerning the Northern Cameroons (Cameroon v. United Kingdom) Judgement [1963] ICJ Rep. 27.; Kunor (2009): i. m., 134.

58 Kunoy (2009): i. m., 35.

59 Continental Shelf Submission of Norway in Respect of Areas in the Arctic Ocean, the Barents Sea and the Norvegian Sea. Executive summary. [Submission of Norway] http://www.un.org/Depts/los/clcs_new/submissions files/nor06/nor_exec_sum.pdf (2011.02.06.) 6.

60 Submission of Norway, 14.; Note from the Russian Federation to the Secretary-General of the U.N. in Reference to Receipt of Submission by Norway, Ref. No. 82/n (Feb. 21, 2007) http://www.un.org/Depts/los/clcs new/submissions_files/nor06/rus_07_00325.pdf (2011.01.29.). 
került rendezni, 2010 végén, Murmanszkban, így a Nyugat-Nansen-medence keleti része tekintetében megszületett a határ. ${ }^{61}$

A többi esetleges területi vita tekintetében, 2006. szeptember 20-án szakértői konzultációkat követően Norvégia, Izland és Dánia külügyminisztere, valamint a Feröer szigetek miniszterelnöke aláírták az Agreed Minutes ${ }^{62}$ elnevezésű megállapodást a Banana-mélyedés déli részének jövőbeni elhatárolásának kérdésében. A megállapodás szerint a szerződő felek a jövőben benyújtandó igényeik esetében hozzájárulnak ahhoz, hogy a CLCS az ajánlását a megállapodást figyelembe véve hozza meg, illetve kötelezik magukat arra, hogy abban az esetben, ha bármelyikük benyújtja igényét a CLCS-hez, a többi állam jegyzékben tájékoztatja a főtitkárt a hozzájárulásáról ahhoz, hogy a CLCS a mindhármukat érintö területek vonatkozásában is kialakíthassa az állásfoglalását. Egyetértettek továbbá abban is, hogy a CLCS javaslata nem befolyásolja a már meglévő, kétoldalú kontinentális talapzat elhatárolási szerződések tartalmát. ${ }^{63} \mathrm{~A}$ végleges határokat ugyanis kétoldalú egyezményekkel fogják rögzíteni az érintett államok, amikor majd az összes részes fél vonatkozásában megszületik a CLCS kötelező erejü állásfoglalása. ${ }^{64}$ Ennek megfelelően terjesztette be a norvég kormány az igényét, Dánia és Izland pedig hivatalos álláspontban fejtette ki, hogy nem mond ellent a beterjesztett norvég igényeknek ${ }^{65} \mathrm{~A}$ norvég igény beadásának napján Dánia és Izland is benyújtotta a CLCS-hez a maga igényét, igaz, ezek az államok kizárólag olyan területrészre, amelyre vonatkozóan más állam potenciális igénye az előzetes kutatások alapján kizárt. ${ }^{66}$

61 Russia and Norway sign Maritime border agreement. 15 Sept. 2010. http://www.bbc.co.uk/news/business-11316430 (2011.03.29.).

62 Agreed Minutes on the Delimitation of the Continental Shelf beyond 200 Nautical Miles between the Faroe Islands, Iceland and Norway in the Southern Part of the Banana Hole of the Northeast Atlantic. http://www. regjeringen.no/en/dep/ud/Documents/Laws-and-rules/retningslinjer/2006/Agreed-Minutes. html?id=446839 (2011.02.03.).

${ }^{63}$ Submission of Norway, 11.

64 Press Release: Norwegian Mission to U.N., Agreement on Continental Shelf in the Norwegian Sea (Sept. 20, 2006), http://www.norway-un.org/News/Archive+2006/Important+agreement.htm (2011.01.29.).

65 Note from Denmark to the Secretary-General of the U.N. in Reference to Receipt of Submission by Norway, Ref. No. 119.N.8 (Jan. 24, 2007) http://www.un.org/Depts/los/clcs_new/submissions_files/nor06/ dnk07_00218.pdf (2011.01.29.); Note from Iceland to the Secretary-General of the U.N. in Reference to Receipt of Submission by Norway, Ref. No. FNY07010008/97.B.512 (Jan. 29, 2007) http://www.un.org/Depts/ los/clcs_new/submissions_files/nor06/isl07_00223.pdf (2011.01.29.).

66 Danish Team Heads for North Pole. BBC NEWS, Aug. 13, 2007. http://news.bbc.co.uk/2/hi/europe/6941134. stm (2011.02.01.); Partial Submission of the Government of the Kingdom of Denmark together with the Government of the Faroes to the Commission on the Limits of the Continental Shelf: The Continental Shelf North of the Faroe Islands. 5.; Ministry of Science, Tech. \& Innovation: The Continental Shelf Project. http:// a76.dk/lang_uk/main.html (2011.02.10.); The Icelandic Continental Shelf. Partial Submission to the Commission of the Limits of the Continental Shelf pursuant to article 76, paragraph 8 of the United Nations Law of the Sea in respect of the /Egir Basin area and Reykjanes Ridge. Part I. Executive Summary. 16. July 2009. 5. http://www.un.org/Depts/los/clcs_new/submissions_files/submission_isl_27_2009.htm (2011.02.09.). 


\section{Geológiai kérdés és a jog: a kiemelkedések és hátságok elhatárolása}

\subsection{Oroszország beadványa és a lavina, amelyet elindított}

Oroszország tekintetében az UNCLOS 1997. április 11-én lépett hatályba. Az állam elsőként élt a lehetőséggel, és 2001. december 20 -án előterjesztette igényét a CLCSnél, ${ }^{67}$ amely a Jeges-tenger alatt húzódó kontinentális talapzat közel felére kiterjed. ${ }^{68}$ [4. ábra]

$A z$ igényelt terület meghatározott részeire azonban több északi állam is igényt tarthat, amelyeket a fötitkár értesített. ${ }^{69}$ Kanada és Dánia - amelyek ekkor még nem is voltak részesei az UNCLOS-nak - úgy nyilatkozott, hogy több információra van szükség ahhoz, hogy az orosz igényeket meg lehessen ítélni. ${ }^{70}$ Norvégia szerint egyértelmüen területi vitáról van szó, amelyet a megfelelő vitarendezési fórum elé kell vinni, ${ }^{71}$ míg az UNCLOS-ban a mai napig nem részes USA egyszerüen csak túlzásként írta le az orosz igényeket. ${ }^{72}$ (Azzal ugyanis, hogy a fötitkár a CLCS-hez érkezett beadványokról az összes ENSZ-tagállamot köteles értesíteni, fel is jogosítja azokat, - még ha az UNCLOS-nak nem is részesei - hogy észrevételeket tegyenek. Ellenkező esetben a CLCS eljárási szabályai eltérően fogalmaznának. ${ }^{73}$ )

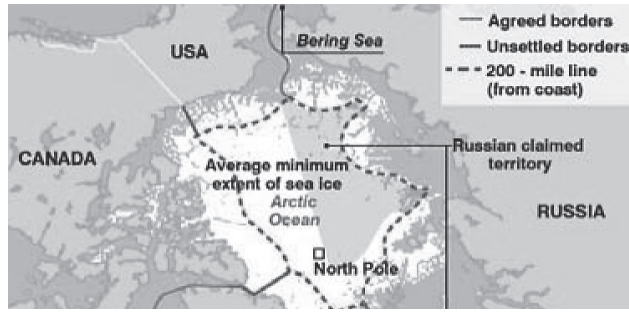

4. ábra - Az orosz igények

Tekintettel arra, hogy az orosz beadványban szereplő térképek egyikén se jelölik pontos koordinátákkal az igényeket, ezért Marc Benitah arra következtetett, hogy az állam nem a mélytengeri hátságokra alapította az igényét, ugyanis az UNCLOS 76. cikk (6) bekezdése tiltja, hogy 350 tengeri mérföldön túli mélytengeri hátságokra terjesszen ki az állam

67 Press Release: Commission on the Limits of the Continental Shelf Receives Its First Submission: Russian Federation First to Move to Establish Outer Limits of Its Extended Continental Shelf, U.N. Doc. SEA/1729 (Dec. 21, 2001).

68 JaRASHOW: i. m., 1587; 1591.; COHEN: i. m., 1-2.

69 JARASHOW: i. m., 1595.

70 Canada: Notification Regarding the Submission Made by the Russian Federation to the Commission on the Limits of the Continental Shelf, Ref No. CLCS.01.2001.LOS/CAN (Feb. 26, 2002) (attaching Canadian submission dated January 18 2002); Denmark: Notification Regarding the Submission Made by the Russian Federation to the Commission on the Limits of the Continental Shelf, Ref. No. CLCS.01.2001.LOS/DNK (Feb. 26, 2002) (attaching Danish submission dated Feburary 4, 2002). JARES: i. m., 1284.

71 Norway: Notification Regarding the Submission Made by the Russian Federation to the Commission on the Limits of the Continental Shelf, Ref. No. CLCS.01.2001.LOS/NOR (Apr. 2, 2002) (quoting Rule 5(a) of Annex I to CLCS, Rules of Procedure of the Commission on the Limits of the Continental Shelf, U.N. Doc. CLCS/40/ Rev.1 (Apr. 17, 2008) [Norway: Notification to Russian Submission], Jares: i. m., 1285.

72 United States of America: Notification Regarding the Submission Made by the Russian Federation to the Commission on the Limits of the Continental Shelf, Ref. No. CLCS.01.2001.LOS/USA (Mar. 18, 2002) (attaching U.S. submission dated February 28, 2002) 2.; JARES: i. m., 1285.

73 Rules of Procedure, 50. 
igényt. ${ }^{74} \mathrm{Az}$ érintett államok nyilatkozatai azért jelentősek, mert Oroszország élt az adatvédelmi lehetőségekkel, így beadványának tartalma - egy térkép kivételével nem nyilvános. ${ }^{75}$

Norvégia kifejtette, hogy a Barents-tenger térségében átfedik egymást a norvég és az orosz igények, blokkolva ezzel az orosz igények elbírálását. ${ }^{76}$ Eljárásjogi szempontból ugyanis, ha a szomszédos vagy szemben lévő állam nem ért egyet az igénylő által beterjesztett határokkal, vagyis a CLCS eljárási szabályai ${ }^{77}$ I. számú mellékletének 5. cikk (a) pontja alapján területi vitáról van szó, akkor a CLCS addig nem bírálhatja el az igénylö beadványát, ameddig az érintett államok meg nem állapodnak.

Az USA ezenfelül arra hivatkozott, hogy az Alpha-Mengyelejev-hátság, továbbá a Lomonoszov-hátság nem tartozik egyetlen állam kontinentális talapzatához sem, hanem a Jeges-tenger medencéjének részeként szabadon álló terület. Mindezt az UNCLOS 76. cikkének 3 . bekezdésére alapozta, amely kimondja, hogy a kontinentális perem a parti állam szárazföldjének elsüllyedt meghosszabbítását foglalja magában, és a talapzat, a lejtő és a küszöb tengerfenekéből és altalajából áll, viszont nem foglalja magában a mélytengeri medrét az óceáni hátságokkal. Az Alpha-Mengyelejev-hátság és a Lomonoszov-hátság vulkanikus eredetű, és mint ilyen, az Izlandi-Feröeri-hátság része, amellyel azonos geológiai jelleget mutat. Az USA szerint ahhoz, hogy az oroszok bebizonyítsák, hogy az Alpha-Mengyelejev-hátság víz alatti, mélytengeri hátság és nem óceáni hátság, ki kell mutatniuk a Lomonoszov-hátság és az orosz kontinentális perem közötti geológiai kapcsolatot. ${ }^{78}$

Harmadrészt az USA arra is kitért, hogy véleménye szerint az Alpha-Mengyelejevhátság kiemelkedései nem felelnek meg a mélytengeri kiemelkedések fogalmának. Mindezt két érvvel támasztották alá. Azt állították, hogy az ilyen sziklák a szárazföldtől távol fordulnak elő a hátságokon, és nem a kontinentális talapzaton. Ezen kívül mindkétfajta kőzet, ami az Alpha-Mengyelejev-hátságon előfordul, északnyugat-kanadai eredetű, és egyébként sem csakis kizárólag az orosz kontinentális talapzaton található ilyen. ${ }^{79}$

A negyedik kritika az USA részéröl az, hogy Oroszország beadványában nem szerepel a mélytengeri hátság elnevezés. Nem azt állítják, hogy az oroszok nem hivatkoztak az UNCLOS 76. cikk (6) bekezdésére, hanem hogy magát az elnevezést mellőzték az egész beadványban. ${ }^{80}$ Természetesen ezért nem lehet visszautasítani az igény elbírálását azon az alapon, hogy az állam nem hivatkozta meg az összes

${ }^{74}$ BenItAH, Marc: Russia's Claim in the Arctic and the Vexing Issue of Ridges in UNCLOS, ASIL, 11. (2007) 27, 287.

75 Rules of Procedure, Annex II. 2.1. SPIELMAN, Brian: An Evaluation of Russia's Impending Claim for Continental Shelf Expansion: Why Rule 5 Will Shelve Russia's Submission, Emory International Law Review, 23 (2009) 325.

76 Norway: Notification to Russian Submission. 1; 3.

77 Rules of Procedure, Annex I.

78 USA: Notification to Russian Submission, 3.; SPIELMAN: i. m., 334.

79 USA: Notification to Russian Submission, 3.

80 USA: Notification to Russian Submission, 2-3.; SPIELMAN: i. m., 335. 
releváns jogszabályi helyet, ${ }^{81}$ de ez a kritika is közelebb visz ahhoz, hogy mi is lehetett Oroszország 2001-es beadványának tartalma.

Kanada és Dánia az a két állam, amelyek igényei leginkább ütközhetnek az orosz igényekkel, mégis ők ketten produkálták a legrövidebb állásfoglalást az orosz igényekkel kapcsolatban. Mindkét állam annyit jelzett, hogy nincs abban a helyzetben, hogy megítélhetné az orosz igények jogszerüségét. ${ }^{82}$

A CLCS végül úgy döntött, hogy a beterjesztett orosz igények alapján nem elegendőek az információk ahhoz, hogy javaslatot tegyen, így azt tanácsolta Oroszországnak, hogy rendezze a tengeri határokat az Arktiszon: a Barents-tengeren a norvégokkal, ${ }^{83}$ a Bering-tengeren pedig az Egyesült Államokkal, ${ }^{84}$ valamint folytassa a kutatásokat, és akkor forduljon újra igénnyel a CLCS-hez. ${ }^{85}$

Az oroszok 2007 nyarán tudományos expedíciót küldtek az északi-sarki tengerfenékhez, ahol kitüzték az orosz zászlót, hogy ezzel is jelezzék a szándékaik komolyságát, ${ }^{86}$ de új igénylést még nem nyújtottak be a CLCS-hez. ${ }^{87}$

\subsection{A kiemelkedések és a hátságok elhatárolása a CLCS eljárásában}

A kontinentális talapzat külső határa meghosszabbítása tekintetében a legfontosabb kérdés, hogy mi minősül kontinentális talapzatnak, ugyanis ezen áll vagy bukik az államok igénye.

Az UNCLOS 76. cikke, mint azt már többször láthattuk, úgy rendelkezik, hogy a kontinentális perem a parti állam szárazföldjének elsüllyedt meghosszabbítását foglalja magában: a talapzat, a lejtő és a küszöb tengerfenekéből és altalajából áll. Nem foglalja magában a mélytengeri medret az óceáni hátságokkal, illetve az alattuk fek-

81 L. CLCS Guidelines, 9.1.4.

82 Canada: Notification Regarding the Submission Made by the Russian Federation to the Commission on the Limits of the Continental Shelf (Feb. 26, 2002), http://www.un.org/Depts/los/clcs_new/submissions_files/ rus01/CLCS_01_2001_LOS_CANtext.pdf (2011.02.10.); Denmark: Notification Regarding the Submission Made by the Russian Federation to the Commission on the Limits of the Continental Shelf (Feb. 26, 2002), http://www.un.org/Depts/los/clcs_new/submissions_files/rus01/CLCS_01_2001_LOS_DNKtext.pdf (2011.02.10.).

83 A megállapodást negyvenévnyi huzavona után végül 2010-ben megkötötték. NEUmAnN, Thilo: Norway and Russia Agree on Maritime Boundary in the Barents Sea and the Arctic Ocean, ASIL, 14 (2010) 32 http:// www.asil.org/files/2010/insights/insights_101109.pdf (2011.09.10.).

84 A tengeri határok tekintetében az oroszok azt a határt vették figyelembe, amelyet az 1990. június 1-jén, az USA és a Szovjetunió tengeri határként megállapított, annak ellenére, hogy az orosz duma nem is ratifikálta azt. United States of America: Notification Regarding the Submission Made by the Russian Federation to the Commission on the Limits of the Continental Shelf. http://www.un.org/Depts/los/clcs_new/submissions files/rus01/CLCS_01_2001_LOS_USAtext.pdf (2011.02.06.) [USA: Notification to Russian Submission] 2.; SPIELMAN: i. m., 331.

85 UN Doc. A/57/57/Add.1. 39.; BAKER, Betsy: Law, Science and the Continental Shelf: the Russian Federation and the Promise of Arctic Cooperation, American University's International Law Review, 25 (2010) 268-269.

86 ReYnolds, Paul: Russia Ahead in Arctic 'Gold Rush, BBC NEWS, Aug. 1. (2007) http://news.bbc.co.uk/2/hi/ in_depth/6925853.stm (2011.01.31.); Russia's Arctic policy to 2020 and Beyond. http://www.arcticprogress. com/2010/11/russias-arctic-policy/ (2011.02.10.).

87 Mcdorman: i. m., 176. 
vő altalajt. A (6) bekezdés pedig kimondja, hogy az (5) bekezdésben megállapított külső határokra vonatkozó mélységi, illetve távolsági limitek ellenére a tenger alatti hátságokon a kontinentális talapzat külső határa nem nyúlhat az attól az alapvonaltól számított 350 tengeri mérföldön túl, ahonnan a parti tenger szélességét mérik. Ez a szabály viszont nem alkalmazható azon tenger alatti kiemelkedésekre, melyek a kontinentális perem természetes alkotóelemei, úgymint a fennsíkjai, magaslatai, fedőkőzete, sziklapadjai és hegynyúlványai.

A legtöbb problémát ezek a rendelkezések jelentik, és az útmutató ennek megítéléséhez próbál segítséget nyújtani. A kérdésnek különös jelentősége van, ugyanis ettől függ többek között az orosz igények megítélése, de a CLCS a norvég igényekkel kapcsolatban is vizsgálta a kérdést, a Vøring-fennsík esetében.

A 76. cikk háromfajta kiemelkedést különböztet meg az óceán talaján: az óceáni hátságokat (oceanic ridges), a tengeri hátságokat (submarine ridges) és a tengeri kiemelkedéseket (submarine elevations), a pontos meghatározásra vonatkozóan viszont semmilyen eligazítást nem ad..$^{88} \mathrm{~A}$ három fogalom megkülönböztetése pedig nem az elnevezésen múlik, hanem geológiai adatokon. ${ }^{89} \mathrm{Az}$ útmutató összefoglalóan hátság elnevezéssel illet különböző geológiai képződményeket, a vulkanikus eredetủektől a tektonikus lemezmozgások eredményeiig, ${ }^{90}$ a felsorolás azonban nem taxatív. ${ }^{91}$

A szakirodalom az óceáni hátság elnevezést nem használja következetesen. Bizonyos esetekben csak olyan hátságot értenek alatta, amely óceáni bazaltsziklából áll, vannak viszont olyan hátságok, amelyek az idők folyamán kontinentális kőzetrétegből óceáni kőzetréteggé alakultak, valamint olyanok is, amelyek a kontinentális perem részeként a kezdetektől jelen voltak, és azóta befolyásolták a perem állapotát, ennélfogva azok morfológiailag, illetve üledékvastagság szempontjából egyediekké váltak. Az útmutató sem definiálja az óceáni, illetve a tengeri hátságokat, hanem azt hangsúlyozza, hogy az ilyenfajta kiemelkedés megítélésének alapja mindig tudományos vizsgálat, amely megállapítja, hogy az vagy a szárazföld meghosszabbított része vagy sem, milyen a morfológiája, alakja, valamint hogy milyen a geológiai kapcsolata a kontinentális peremmel. ${ }^{92}$ Emiatt a CLCS a hátságok esetenkénti vizsgálatát vezette be, és nem általános szabályozás alá próbálja besorolni őket. ${ }^{93}$

A tenger alatti kiemelkedéseket fennsík, magaslat, fedőkőzet, sziklapad és hegynyúlvány elnevezéssel is illeti az UNCLOS 76. cikkének (6) bekezdése. A felsorolás itt is csak példálózó, viszont közös annak elemeiben, hogy mind a kontinentális perem szerves részei, alkotóelemei, annak kialakulási folyamatának részei (így a kontinensek növekedési fázisának részesei, amelynek alapján létezik aktív és passzív perem). Eszerint közös bennük, hogy a perem részeként a szárazfölddel alaktanilag folytonosak, kőzettanilag azonos felépítésúek, és azonos eredetủek, azonos fejlődési utat

88 CLCS Guidelines 7.1.7.

89 CLCS Guidelines 7.1.8.

90 CLCS Guidelines 7.2.1.

91 CLCS Guidelines 7.2.2.

92 CLCS Guidelines 7.2.10.; NoyEs, John E.: Judicial and Arbitral Proceedings and the Outer Limits of the Continental Shelf, Vanderbilt Journal of Transnational Law, 42 (2009) 1227.

93 CLCS Guidelines 7.2.11. 
jártak be. A tengeri hátságokra is részben igazak ezek a feltételek, de nem egyszerre az összes, és ez a fö különbség a két kategória között. ${ }^{94}$

Az útmutató rendelkezéseiből kiderül, hogy bár geológiában jártas szakértők készítették, tulajdonképpen nem jelent igazi fogódzót sem a CLCS, sem az igénnyel fellépő állam számára; és ráadásul joggyakorlat sem alakulhatott még ki ebben a kérdésben, tekintettel arra, hogy például azok az arktiszi államok is, amelyeknek igénye átfedésbe került volna más államok igényével - Oroszországot kivéve - kizárólag olyan területekre nézve nyújtottak be igényt, amely területek vonatkozásában átfedési probléma nem áll fenn.

Az egyetlen arktiszi példának a Vøring-fennsík tekinthető, amely hatalmas, 1300 1500 méter mélyen elhelyezkedő képződmény, és a Norvégia által beterjesztett adatok alapján egyértelmü, hogy tengeri kiemelkedés, amely a norvég kontinentális perem természetes alkotóeleme. A tőle északnyugatra húzódó Vøring-hegynyúlvány ezzel szemben az adatok alapján ugyan a norvég szárazföld tenger alatti folytatása, de az adatok alapján az is látszik, hogy a fennsíktól teljesen eltérő fejlődéstörténeti és geológiai jellege van, így a CLCS véleménye alapján nem tekinthető olyan tenger alatti kiemelkedésnek, amely a kontinentális perem természetes alkotórésze..$^{95}$

A probléma gyakorlati megjelenése elsősorban az orosz igényekkel kapcsolatos, amelyeket azonban - mint láttuk - nem támasztottak alá kellő geológiai bizonyítékkal ahhoz, hogy a CLCS ajánlást tudjon tenni a kontinentális talapzatuk 200 tengeri mérföldön túli, külső határára. A vitatott területet két, a szibériai szárazföldtöl egészen Grönlandig húzódó, hatalmas tenger alatti hegységrendszer, a Lomonoszov-és az Alpha-Mengyelejev-hátság foglalja el. Kérdés, hogy ezek vajon minek minősülnek: óceáni hátságnak, tengeri hátságnak vagy tengeri kiemelkedésnek. Oroszország azt állítja, hogy a hátságok az eurázsiai kontinentális perem természetes alkotóelemei, így az UNCLOS 76. cikk (6) bekezdése szerinti tengeri kiemelkedések. Dánia és Kanada viszont az észak-amerikai kontinens kontinentális peremének részeként tekint rájuk, az USA szerint pedig önálló alakzatokról van szó, amelyek egyik állam kontinentális peremének sem részei. ${ }^{96}$

Egyelöre a CLCS gyakorlata nem ad igazodási pontot a még el nem bírált igények jövőjére nézve. A norvég-dán-izlandi példa a CLCS előtti eljárást megelőző kooperáció fontosságára hívja fel a figyelmet, azonban arra az esetre is gondolni kell, hogy az esetleges vitás kérdéseket nem tudják egymás között megoldani az államok. ${ }^{97}$

\section{4. Összegzés és következtetések}

Az államok kontinentális talapzat iránti igénye mindig is fennállt, és eddig is számos esetben szolgált vita tárgyául, elsősorban az egymás közötti határok megállapítása

${ }_{94}$ CLCS Guidelines 7.3.1.

95 CLCS Recommendation to Norway 73-74.

96 SPIELMAN: i. m., 333-334.

97 MURPHY, Ireland: Coordinated, Harmonized or Joint Submissions to the Commission on the Limits of the Continental Shelf. http://www.gmat.unsw.edu.au/ablos/ABLOS08Folder/Session2-Paper1-Murphy.pdf (2011.02.19.). 
miatt. Az 1982-es tengerjogi egyezmény azonban egy új vitasíkot nyitott meg a 200 tengeri mérföldön túli talapzatrészek külső határai tekintetében, amire kiemelkedő példa az arktiszi harc a víz alatti nyersanyagforrásokért. Ez a 2007-es orosz expedíció révén vált közismertté, amikor az állam képviselői titánzászlót tủztek az Északi-sark alatti tengerfenékre, szimbolikusan jelezve a területi igényeket. Ez az incidens világított rá először arra a problémakörre, ami a mai napig nem tisztázott: melyik államot és milyen arányban illeti meg az Északi-sarkvidék alatt húzódó, kiaknázatlan erőforrásokban igen gazdag, kontinentális talapzat.

A versengés mögött olyan, tisztázandó jogi problémák húzódnak, amelyek legtöbbször nem kerülnek át a köztudatba. Ezek mindegyike a Kontinentális Talapzat Bizottság müködésével függ össze: az UNCLOS szabályai és a még nem csatlakozott államokat megillető jogok a kontinentális talapzathoz, az igénybenyújtásra rendelkezésre álló 10 éves időkorlát értelmezése, valamint az UNCLOS geológiai fogalmai és azok jelentéstartalma a jogi szövegkörnyezetben.

A kontinentális talapzat 200 tengeri mérföldön túli részeinek külső határa azonban szükségképpen megállapításra vár, hiszen addig nem tudni, hol végződik az állam, és hol kezdődik a Nemzetközi Tengerfenék Hatóság joghatósága. Ez utóbbi ugyanis a tengerfeneket mint az emberiség közös örökségét jogosult szabályozási körébe vonni. Márpedig az Arktisz speciális ökoszisztémája és védelmi szükségletei szempontjából, valamint a jelentős kiaknázásra váró nyersanyagok miatt erről mielőbb dönteni kell.

\section{Abstract}

The concept of continental shelf as an inherent right to coastal State has a history of almost a hundred year but its legal status has several gaps which need to be resolved in the forseeable future. Delimitation of continental shelf between States with adjacent or opposite coasts has been a problematic issue since the elaboration of the legal concept of continental shelf but the present essay aims to highlight some other problems emerging since the first application of Article 76 of UNCLOS. These legal problems are related to the procedure of establishing of the outer limits of continental shelf beyond 200 nautical miles. The essay examines these legal problems and demonstrates the challenge caused to the Arctic continental shelf as an example. 